\title{
Research on China's Virtual Water Trading Regarding the Differences between Countries and Industries from the Global Perspective
}

\author{
Guangyao Deng1*, Yunjiang Liu ${ }^{2}$ \\ ${ }^{1}$ School of Statistics, Lanzhou University of Finance and Economics, Lanzhou 730020, P. R. China \\ ${ }^{2}$ School of Law, Shanghai University of Finance and Economics, Shanghai 200433, PR China
}

Received: 28 May 2020

Accepted: 11 October 2020

\begin{abstract}
From the global perspective, this paper utilizes the multi-regional input-output table and water footprint data from the EORA26 database to study China's virtual water trading in the year of 2015. The research results indicate that (1) China was a net exporter of virtual water for all the three types of water footprints: green, blue and grey. In addition, among all the major trading partners, China imported the most amount of virtual water from Germany and the biggest importer of China's virtual water was the US. (2) When the amounts of green, blue and grey water are added up, the largest industry of imported virtual water usage was agriculture, while the textiles and wearing apparel industry exported the largest volume of virtual water. However, when only grey water is considered, China's electrical and machinery industry both imported and exported the highest amounts of virtual water.
\end{abstract}

Keywords: virtual water trade, multi-regional input-output model, green water, blue water, grey water

\section{Introduction}

Water resource is indispensable for sustaining the economic growth. The increasing demand for water due to the fast development of China's economy, together with the uneven distribution of China's water supplies in time and space, has made the imbalance between supply and demand more and more severe. Besides the commonly used methods to solve such problem such as improving the efficiency of water use and building trans-basin water pipelines [1], some researchers have advised that the import of products from water-rich

*e-mail: dgy316203@163.com areas (referred to as virtual water trade) can be an alternative solution to address the problems of water shortage in China [2]. The term virtual water refers to the amount of water needed to produce certain goods or to provide certain services [3].

Based on the idea of virtual water, Hoekstra and Hung [4] further proposed the concept of water footprint, which refers to the total amount of water needed for one country (region), one industry or one person to produce certain goods or to provide certain services. The water footprint has three components: green, blue and grey. Green water footprint is water from precipitation that is stored in the root zone of the soil and evaporated, transpired or incorporated by plants; blue water footprint is water that has been sourced from surface or groundwater resources and is either evaporated, 
incorporated into a product or taken from one body of water and returned to another, or returned at a different time; grey water footprint is the amount of fresh water required to assimilate pollutants to meet specific water quality standards [5]. Current studies of water footprint mainly focus on the level of individual product or the level of macro-industry (economic sector).

On the individual product level, Dang et al. [6] conducted a research on the virtual water trade of US agricultural products, pointing out that the volume of virtual water trade within the US accounted for 51\% of global trade. Sun et al. [7] studied the virtual water trade of each province and eight regions of China in terms of food commodities, indicating that Northeast China and the Huang-Huai-Hai Plain (Huang: the Yellow River; Huai: the Huaihe River; Hai: the Haihe River) were the major regions for grain production as well as for virtual water export. Zhuo et al. [8] looked at the virtual water trade of China's eight regions from 1978 to 2008, concluding that the net flow of virtual water within China was from the water-rich South to the water-scarce North before 2000; however, the growing North-to-South crop trade reversed that direction since 2000 , which accounted for $6 \%$ of North China's water footprint of crop production in 2008. Zhang et al. [9] examined the net virtual water trade between China and countries in TPP (Transpacific Partnership Agreement) on agricultural products from 2001 to 2014, showing that China enjoyed an increasing surplus for virtual water trade with TPP countries on agricultural products. Lamastra et al. [10] investigated the virtual water trade between China and Italy on agricultural products from 2010 to 2015, demonstrating that Italy was a net importer of virtual water from China; $91 \%$ of the virtual water imported by Italy was related to crop products, while $95 \%$ of the virtual water imported by China originated from animal products. The abovementioned literatures provide a general guidance to calculate the amount of virtual water trade on the level of individual product. At first, the quantities of water consumed by a crop or an animal at every stage during its growth are added up according to the corresponding weight determined by the value factors and scaling factors specific to that product. Then, the so-calculated amount of virtual water within that product is multiplied by the corresponding trade volume to get the amount of virtual water trade. Although this above approach has the advantage to simultaneously calculate the trade volumes of green, blue and grey virtual water, the actual calculation is quite complicated; therefore, it is mainly used for agricultural products.

On the level of macro-industry, Dong et al. [11] used a multi-regional input-output model to study the water footprint and the virtual water trade of each province in China, concluding that Xinjiang, Jiangsu, Heilongjiang, Inner Mongolia, Guangxi and Hunan were the main water import regions. Jiang et al. [12] examined the 2007 virtual water trade data of each province in China, pointing out that some water-scarce provinces were still net virtual water exporters (such as Ningxia, Hebei and Xinjiang) while some water-deficit and most-developed regions (such as Beijing and Tianjin) relied heavily on external water sources. Zhi et al. [13] implemented a factor decomposition analysis by weighted average decomposition model on the changes of Chinese virtual water consumption between 2002 and 2007, pointing out that the increase in net VW exports was mainly due to the economic structure effect and the fast growth of exports. Serrano et al. [14] researched 27 EU states on their virtual water trade data and found out that Germany became a key net importer of water in Europe through the trade of agricultural products, foods, chemicals, and electricity. Zhi et al. [15] described the intermediate water footprint products of each sector in a material-product network, and found out that the top three sectors with the largest water footprint in China were agriculture, food and machinery manufacturing in 2016. In line with the above literature, the amount of virtual water trade on the macro-industry level of one country (region) is usually calculated through an input-output model. First, a direct water use coefficient is obtained through the total input of all industries and water usage data. Then, a Leontief inverse matrix is adopted to get the overall water-use coefficient, which is multiplied by the corresponding trade volume of a particular industry to provide the amount of virtual water trade of that industry.

All those sources have reported a lot of studies on virtual water trade and provided many valuable insights. In another aspect, China is importing or consuming goods from all over the world in today's globalized economy. However, the existing literature shave not yet provided any detailed information about the sources of imports and destinations of exports in terms of China's virtual water trade from the perspective of global value chains. This work focuses on the following two aspects. The first objective is to account the size of China's virtual water trade based on the perspective of global value chains. Through such process this work was able to subdivide the overall amount of China's virtual water trade according to different trading partners and industries, while the existing literatures $[16,17]$ only covered the difference between industries without providing any detailed information about the exact amount of virtual water import from a particular country (or export to a particular country) by a particular industry in China. Secondly, due to the limitation of data availability, the existing works usually turned to some statistical yearbooks for China's water usage data, which were limited to blue water. Therefore, some existing studies just focused on the blue water aspect of China's virtual water trade and did not investigate the green and grey segments [18]. By using the global multi-regional input-output table and the resource data on green, blue and grey water footprints from the EORA database, this work systematically and comprehensively analyzes China's virtual water trade with regard to all types of virtual water resources. 


\section{Material and Methods}

Data

All the data used in this work come from the EORA database $[19,20]$. According to the purpose of this research, the EORA26 sub-database was chosen for this work. Up to now, EORA26 database has provided world input-output tables and environmental accounting data among 190 countries from 1990 to 2015. Water use data for green water, blue water and grey water in 26 departments over 190 countries are included in the environmental accounting data. Due to the complex procedure of making world input-output tables and calculating water footprint, the 2015 data is already the latest, so this paper chooses to study on the 2015 data.

It should be noted that the green, blue and grey water footprint data provided by the EORA26 sub-database are only estimated data. It can be seen from a calculation that, for those 26 industrial sectors in China, the direct water-use coefficients are the same for each year in the range of 1990-2015 (e.g. the direct water-use coefficient for China's agricultural sector in 2015 is the same as that in 2014). Therefore, this study includes neither the trend analysis for China's virtual water trade from 1990 to 2015 nor the structural decomposition analysis for the trading volume changes during that period.

\section{Methods}

In accordance with the creation method of an input-output table in the EORA database [19, 20], Table 1 shows the structure of an input-output table in EORA 26.
According to the structure of an input-output table in Table 1, a multi-regional input-output (MRIO) model has been established as below [21, 22]:

$$
\mathrm{AX}+\mathrm{Y}=\mathrm{X}
$$

...where $\mathrm{A}$ is an $m n \times m n$ matrix of direct consumption coefficients. An element, of that matrix represents the direct consumption coefficient applied to a product of industry $j$ in region $s$ by a product of industry $i$ in region $r . \mathrm{Y}$ is an $m n \times 1$ column vector of final use (the $m n \times n$ matrix of final use in Table 1 is merged into an $m n \times 1$ one). $\mathrm{X}$ is an $m n \times 1$ column vector of total outputs. From Equation (1) it can be derived that

$$
\mathrm{X}=(\mathrm{I}-\mathrm{A})^{-1} \mathrm{Y}=\mathrm{LY}
$$

...where $\mathrm{I}$ is an $m n \times m n$ identity matrix and $\mathrm{L}=(\mathrm{I}-\mathrm{A})^{-1}$ is an $m n \times m n$ Leontief inverse matrix. The direct water use coefficient in this work is defined as

$$
\mathrm{w}_{j}^{r}=\frac{W_{j}^{r}}{X_{j}^{r}}
$$

...where $W_{j}^{r}$ is the water footprint value of industry $j$ in region $r$ (green, blue and grey water footprints) and $X_{j}^{r}$ is the total input of industry $j$ in region $r$. The direct water-use coefficients are written in the form of a $1 \times m n$ vector, which is multiplied by the Leontief inverse matrix to obtain the overall water-use coefficient as

$$
\overline{\mathrm{W}}=w L=w(I-A)^{-1}
$$

Table 1 The structure of an input-output table in EORA26.

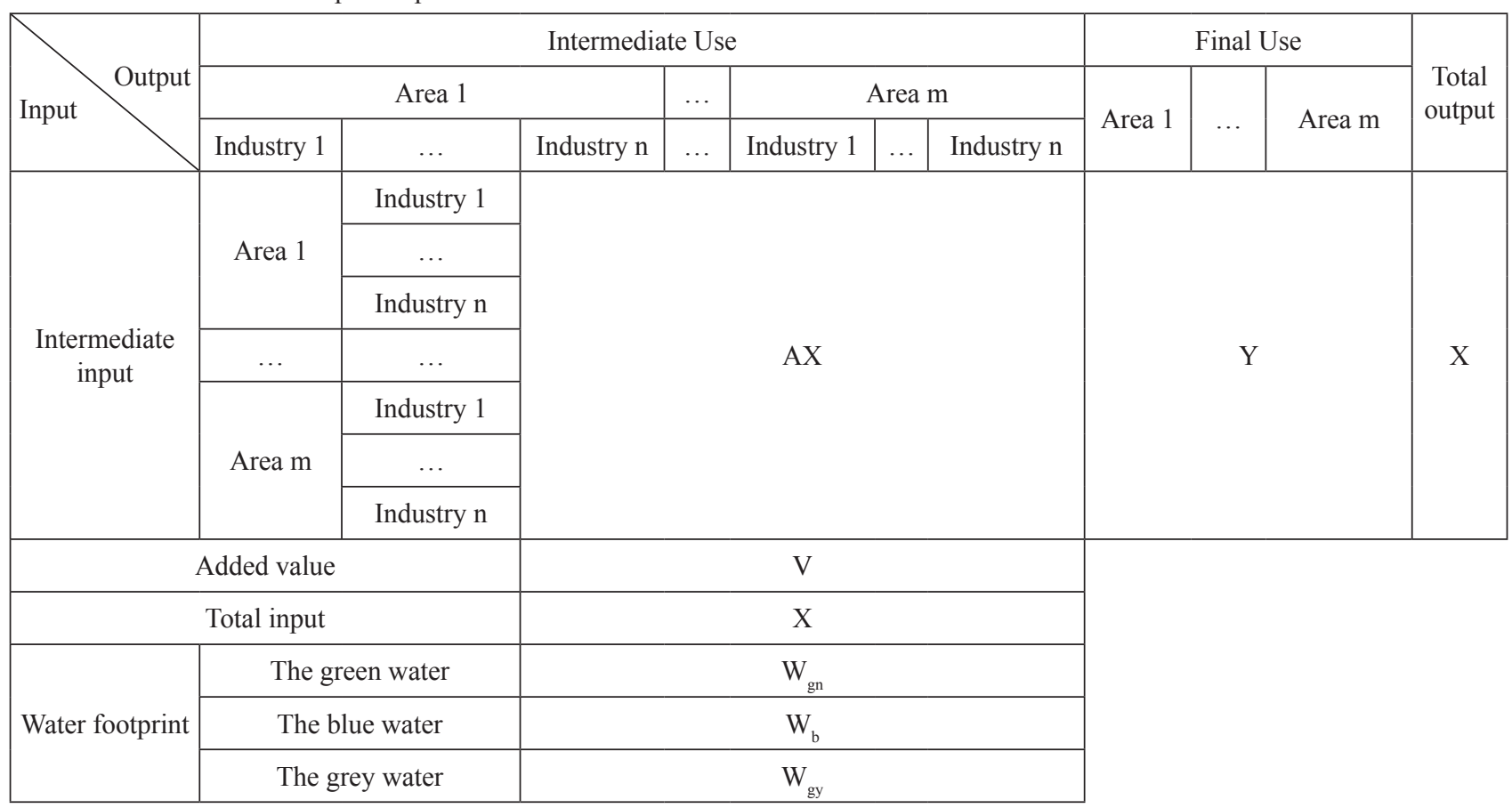


Combing the overall water-use coefficient and the final usage matrix, one can then obtain the amount of virtual water import of region $r$ from region $s$ as well as the amount of virtual water export from region $r$ to region $t$ :

$$
\begin{gathered}
v w i^{s r}=\sum_{j=1}^{n}\left(\bar{w}_{j}^{s r} Y_{j}^{s r}\right) \\
v w i^{r t}=\sum_{j=1}^{n}\left(\bar{w}_{j}^{r t} Y_{j}^{r t}\right)
\end{gathered}
$$

Similarly, the equations to calculate the import and export amounts of virtual water, respectively, for industry $j$ in region $r$ are listed below as

$$
\begin{aligned}
& v w i^{r}=\sum_{\mathrm{s} \neq r}^{m}\left(\bar{w}_{j}^{s r} Y_{j}^{s r}\right) \\
& v w i^{r}=\sum_{\mathrm{t} \neq r}^{m}\left(\bar{w}_{j}^{r t} Y_{j}^{r t}\right)
\end{aligned}
$$

\section{Results and Discussion}

The Difference between Countries Regarding China's Import and Export of Virtual Water

As pointed out previously, the EORA26 subdatabase covers 190 countries (regions). For the sake of clear comparison, this study selects 9 countries that are China's major trading partners of virtual water (Australia, Canada, France, German, Japan, Korea,
Russia, UK and US) ${ }^{1}$, and the data belonging to all the other countries (regions) are grouped as ROW (rest of the world). The amounts of China's virtual water imports and exports in 2015 are listed in Table 2.

From the data listed in Table 2 it can be concluded that:

1) Based on the totals in the last row, China was a net importer of virtual water (no matter in the forms of green, blue or grey water) in 2015. The amount of net export of green water was $16.9896 \times 10^{9} \mathrm{~m}^{3}$, of blue water $18.2095 \times 10^{9} \mathrm{~m}^{3}$, and of grey water $135.2599 \times 10^{9} \mathrm{~m}^{3}$.

Although the water resources in China are relatively short in supply, the calculation results indicate a net export of virtual water.

In 2015 the amounts of green water imported to China from Australia, Canada, Germany, Korea and Russia were greater than corresponding amounts exported from China to those countries; however, China exported less green water to French, Japan, UK, US and ROW than it imported from those countries (regions).

With respect to blue water and the totals listed in the last column, except for Australia, German and Russia, the amounts of virtual water export from China to most countries (regions) in 2015 was greater than those imported from those countries (regions) to China. With respect to grey water, China exported more to most countries (regions) than it imported from those countries (regions) in 2015 (the only exception was Russia).

The volumes of goods and services China exported to or imported from a certain country (region) in 2015 were fixed. However, the water-use coefficients of green, blue and grey water for different industries could be different, even within that same country (region). Thus, the calculated amounts of virtual water imports and

Table 2. The amounts of China's virtual water imports and exports in 2015 by different industries (unit: $10^{9} \mathrm{~m}^{3}$ ).

\begin{tabular}{|c|c|c|c|c|c|c|c|c|}
\hline \multirow{2}{*}{$\begin{array}{c}\text { Country/ } \\
\text { region }\end{array}$} & \multicolumn{2}{|c|}{ Green water } & \multicolumn{2}{c|}{ Blue water } & \multicolumn{2}{c|}{ Grey water } & \multicolumn{2}{c|}{ Total } \\
\cline { 2 - 10 } & Import & Export & Import & Export & Import & Export & Import & Export \\
\hline Australia & 13.4527 & 5.1686 & 1.8286 & 0.8552 & 0.8154 & 2.6477 & 16.0967 & 8.6715 \\
\hline Canada & 8.4424 & 7.2453 & 0.4594 & 1.2661 & 1.2944 & 4.8539 & 10.1962 & 13.3652 \\
\hline France & 6.3898 & 7.0903 & 0.8519 & 1.2416 & 0.6189 & 3.4865 & 7.8606 & 11.8183 \\
\hline German & 25.2550 & 14.4898 & 3.4891 & 2.5507 & 2.1873 & 7.4230 & 30.9314 & 24.4635 \\
\hline Japan & 21.9456 & 48.1066 & 3.1402 & 8.6332 & 1.8394 & 19.2980 & 26.9252 & 76.0378 \\
\hline Korea & 14.2626 & 13.9887 & 2.1567 & 2.4568 & 1.4955 & 6.4501 & 17.9148 & 22.8956 \\
\hline Russia & 18.0445 & 4.7905 & 1.1994 & 0.8923 & 5.7079 & 2.5252 & 24.9518 & 8.2081 \\
\hline U.K. & 5.3750 & 10.9697 & 0.7515 & 1.8964 & 0.3865 & 6.6287 & 6.5130 & 19.4947 \\
\hline U.S. & 18.5974 & 75.9905 & 2.7454 & 12.9620 & 2.9505 & 37.8494 & 24.2932 & 126.8019 \\
\hline ROW & 183.2079 & 144.1196 & 23.6076 & 25.6852 & 14.0709 & 75.4641 & 220.8864 & 245.2689 \\
\hline Total & 314.9727 & 331.9596 & 40.2299 & 58.4394 & 31.3666 & 166.6265 & 386.5693 & 557.0256 \\
\hline
\end{tabular}

The above 9 countries are chosen because they have a relatively large bilateral trade volume with China. 
Table 3. China's virtual water imports and exports in 2015 by different industries (unit: $10^{9} \mathrm{~m}^{3}$ ).

\begin{tabular}{|c|c|c|c|c|c|c|c|c|}
\hline \multirow{2}{*}{ Industry } & \multicolumn{2}{|c|}{ Green water } & \multicolumn{2}{|c|}{ Blue water } & \multicolumn{2}{|c|}{ Grey water } & \multicolumn{2}{|c|}{ Total } \\
\hline & Import & Export & Import & Export & Import & Export & Import & Export \\
\hline 1 & 109.4676 & 22.7852 & 11.4156 & 4.2207 & 6.6979 & 7.7453 & 127.5812 & 34.7512 \\
\hline 2 & 1.9464 & 0.6119 & 0.1123 & 0.0873 & 0.1494 & 0.1602 & 2.2081 & 0.8594 \\
\hline 3 & 0.2713 & 0.0829 & 0.0362 & 0.0153 & 0.0605 & 0.0425 & 0.3680 & 0.1407 \\
\hline 4 & 63.7974 & 40.1120 & 7.4968 & 6.8425 & 5.3798 & 11.5752 & 76.6739 & 58.5297 \\
\hline 5 & 13.3745 & 105.7824 & 2.9858 & 20.3829 & 1.8110 & 32.7393 & 18.1713 & 158.9046 \\
\hline 6 & 1.8902 & 8.0786 & 0.1947 & 0.9989 & 0.1963 & 4.6945 & 2.2812 & 13.7721 \\
\hline 7 & 3.9633 & 8.2257 & 0.5761 & 1.4551 & 0.4212 & 3.8625 & 4.9606 & 13.5433 \\
\hline 8 & 2.3150 & 3.9482 & 0.3416 & 0.7877 & 0.3665 & 11.7585 & 3.0231 & 16.4945 \\
\hline 9 & 77.0336 & 64.2595 & 11.2908 & 11.4635 & 8.0160 & 56.0495 & 96.3405 & 131.7725 \\
\hline 10 & 13.1283 & 5.9468 & 2.0211 & 1.1084 & 5.4926 & 4.8684 & 20.6420 & 11.9236 \\
\hline 11 & 2.1925 & 47.7927 & 0.2970 & 6.8992 & 0.3174 & 16.1507 & 2.8069 & 70.8426 \\
\hline 12 & 1.0481 & 0.0405 & 0.1273 & 0.0702 & 0.1421 & 6.6115 & 1.3174 & 6.7223 \\
\hline 13 & 0.0188 & 0.0238 & 0.0030 & 0.0042 & 0.0031 & 0.0118 & 0.0249 & 0.0398 \\
\hline 14 & 3.9117 & 0.7740 & 0.5632 & 0.1266 & 0.5112 & 0.4196 & 4.9861 & 1.3203 \\
\hline 15 & 0.0238 & 0.1204 & 0.0034 & 0.0186 & 0.0017 & 0.0443 & 0.0289 & 0.1833 \\
\hline 16 & 0.0764 & 1.5525 & 0.0114 & 0.2400 & 0.0077 & 0.5708 & 0.0955 & 2.3632 \\
\hline 17 & 0.1564 & 3.4531 & 0.0223 & 0.5337 & 0.0163 & 1.2695 & 0.1950 & 5.2564 \\
\hline 18 & 0.1267 & 9.7894 & 0.0151 & 1.6528 & 0.0109 & 3.0583 & 0.1527 & 14.5005 \\
\hline 19 & 1.6959 & 3.3457 & 0.2489 & 0.6779 & 0.1850 & 2.8442 & 2.1299 & 6.8678 \\
\hline 20 & 0.3086 & 0.1494 & 0.0498 & 0.0240 & 0.0241 & 0.0625 & 0.3825 & 0.2359 \\
\hline 21 & 2.6977 & 1.9451 & 0.3702 & 0.3096 & 0.2073 & 0.8186 & 3.2752 & 3.0734 \\
\hline 22 & 0.1392 & 0.0000 & 0.0188 & 0.0000 & 0.0133 & 0.0000 & 0.1713 & 0.0000 \\
\hline 23 & 4.2555 & 3.0928 & 0.5873 & 0.5121 & 0.3101 & 1.2553 & 5.1528 & 4.8602 \\
\hline 24 & 0.1594 & 0.0354 & 0.0219 & 0.0062 & 0.0106 & 0.0130 & 0.1920 & 0.0545 \\
\hline 25 & 0.0801 & 0.0001 & 0.0118 & 0.0000 & 0.0062 & 0.0000 & 0.0980 & 0.0001 \\
\hline 26 & 10.8943 & 0.0115 & 1.4073 & 0.0020 & 1.0088 & 0.0004 & 13.3103 & 0.0139 \\
\hline Total & 314.9727 & 331.9596 & 40.2299 & 58.4394 & 31.3666 & 166.6265 & 386.5693 & 557.0256 \\
\hline
\end{tabular}

Note: The industry codes are used as: Agriculture (1), Fishing (2), Mining and Quarrying (3), Food \& Beverages (4), Textiles and Wearing Apparel (5), Wood and Paper (6), Petroleum, Chemical and Non-Metallic Mineral Products (7), Metal Products (8), Electrical and Machinery (9), Transport Equipment (10), Other Manufacturing (11), Recycling (12), Electricity, Gas and Water (13), Construction (14), Maintenance and Repair (15), Wholesale Trade (16), Retail Trade (17), Hotels and Restaurants (18), Transport (19), Post and Telecommunications (20), Financial Intermediation and Business Activities (21), Public Administration (22), Education, Health and Other Services (23), Private Households (24), Others (25), Re-export \& Re-import (26).

exports between China and those countries (regions) might still be different (in terms of green, blue and grey water footprints), a situation as shown in Table 2.

2) With respect to virtual water trade in terms of green, blue and grey water footprints, except for ROW, China imported most virtual water from Germany $\left(30.9314 \times 10^{9} \mathrm{~m}^{3}\right)$ and exported most virtual water to the US $\left(126.8019 \times 10^{9} \mathrm{~m}^{3}\right)$. Moreover, in comparison with blue and grey water footprints, green water had the largest portion of total virtual water trade between China and its major trading partners. In that sense, there are limitations that some works [21] only focused on the trade of virtual water in the form of blue water.

The Difference between Industries Regarding China's Import and Export of Virtual Water

The virtual water import \& export situation of various industries in China in 2015 is shown in Table 3. 
It can be concluded from Table 3 that:

1) The industry that imported the most amount of green water to China in 2015 was agriculture $\left(109.4676 \times 10^{9} \mathrm{~m}^{3}\right)$. In one aspect, China imports a huge number of agricultural products each year. In the other aspect, the definition of green water, which is water from precipitation that is stored in the root zone of the soil and evaporated, transpired or incorporated by plants, tells that agricultural production itself will consume a large amount of green water, resulting in a large direct water-use coefficient and a large overall water-use coefficient. Therefore, the calculation by Equation (7) will lead to the finding that China's agricultural industry imported the largest amount of green water.

In addition, China's textiles and wearing apparel industry (5) exported the largest amount of green water in $2015\left(105.7824 \times 10^{9} \mathrm{~m}^{3}\right)$, due to the big volume of textile products manufactured in and exported from China.

2) With respect to blue water, the industry that imported the most amount of virtual water to China in 2015 was still agriculture $\left(11.4156 \times 10^{9} \mathrm{~m}^{3}\right)$. One reason lies in the fact that the growth of agricultural products requires a significant amount of blue water from river, lake and ground water; another reason is China's large volume of agricultural imports. Furthermore, the industry that exported the most amount of virtual water from China in 2015 was textiles and wearing apparel $\left(20.3829 \times 10^{9} \mathrm{~m}^{3}\right)$.

3) China's largest industries to export and export grey water in 2015 was electrical and machinery industry (9). The manufacturing process of electrical and machinery goods generates a lot of polluted water, whose purification requires large inputs of resources. On one hand, this industry bears a large direct water- use coefficient and overall water-use coefficient for grey water; on the other hand, this industry in China both exported and imported large volumes of related products in 2015. According to Equation (7) and Equation (8), this industry thus imported to and exported from China the largest amounts of grey water in 2015.

4) With respect to the totals of green, blue and grey water, in 2015 China's agricultural industry imported the biggest amount of virtual water $\left(127.5812 \times 10^{9} \mathrm{~m}^{3}\right)$ while the textiles and wearing apparel industry exported the largest amount of virtual water $\left(158.9046 \times 10^{9} \mathrm{~m}^{3}\right)$. In addition, when looking at the total for each industry, one can find that China imported less virtual water than it exported no matter in the form of green, blue or grey water. That finding is in accordance with that drawn from the totals for those countries (regions) in Table 2.

In order to analyze the difference between countries regarding the import and export of virtual water by each industry in China in 2015, we take the agricultural industry as an exemplar, and the detailed results are shown in Table 4.

It can be concluded from the data in Table 4 that:

1) Except for ROW, in 2015 the top sources of green water import by China's agricultural industry were US, Russia and Australia (6.9693 $\times 10^{9} \mathrm{~m}^{3}$, $6.5873 \times 10^{9} \mathrm{~m}^{3}$ and $5.8116 \times 10^{9} \mathrm{~m}^{3}$, respectively), and the top destinations of green water export by China's agricultural industry were Japan, German and Korea $\left(1.9503 \times 10^{9} \mathrm{~m}^{3}, 1.3995 \times 10^{9} \mathrm{~m}^{3}\right.$ and $\left.1.2914 \times 10^{9} \mathrm{~m}^{3}\right)$.

2) Except for ROW, in 2015 China's agricultural industry imported most blue water from US $\left(1.0654 \times 10^{9} \mathrm{~m}^{3}\right)$ and exported most blue water to Japan $\left(0.3613 \times 10^{9} \mathrm{~m}^{3}\right)$.

3) Except for ROW, in 2015 China's agricultural industry imported most grey water from US

Table 4. Differences between countries regarding the import and export of virtual water by China's agricultural industry in 2015 (unit: $10^{9} \mathrm{~m}^{3}$ ).

\begin{tabular}{|c|c|c|c|c|c|c|c|c|}
\hline \multirow{2}{*}{$\begin{array}{c}\text { Country/ } \\
\text { region }\end{array}$} & \multicolumn{2}{|c|}{ Green water } & \multicolumn{2}{c|}{ Blue water } & \multicolumn{2}{c|}{ Grey water } & \multicolumn{2}{c|}{ Total } \\
\cline { 2 - 10 } & Import & Export & Import & Export & Import & Export & Import & Export \\
\hline Australia & 5.8116 & 0.1251 & 0.8726 & 0.0232 & 0.4471 & 0.0425 & 7.1313 & 0.1907 \\
\hline Canada & 3.8522 & 0.4630 & 0.0837 & 0.0858 & 0.5745 & 0.1574 & 4.5104 & 0.7061 \\
\hline France & 0.6411 & 0.7419 & 0.0409 & 0.1374 & 0.0740 & 0.2522 & 0.7560 & 1.1315 \\
\hline German & 0.7381 & 1.3995 & 0.0343 & 0.2592 & 0.1686 & 0.4757 & 0.9411 & 2.1344 \\
\hline Japan & 0.1163 & 1.9503 & 0.0136 & 0.3613 & 0.0104 & 0.6630 & 0.1403 & 2.9745 \\
\hline Korea & 0.0812 & 1.2914 & 0.0091 & 0.2392 & 0.0091 & 0.4390 & 0.0994 & 1.9697 \\
\hline Russia & 6.5873 & 0.4186 & 0.2690 & 0.0775 & 0.2844 & 0.1423 & 7.1407 & 0.6385 \\
\hline U.K. & 0.0723 & 0.1103 & 0.0040 & 0.0204 & 0.0118 & 0.0375 & 0.0881 & 0.1682 \\
\hline U.S. & 6.9693 & 1.0039 & 1.0654 & 0.1860 & 1.2844 & 0.3413 & 9.3191 & 1.5311 \\
\hline ROW & 84.5982 & 15.2813 & 9.0230 & 2.8307 & 3.8336 & 5.1945 & 97.4548 & 23.3065 \\
\hline Total & 109.4676 & 22.7852 & 11.4156 & 4.2207 & 6.6979 & 7.7453 & 127.5812 & 34.7512 \\
\hline
\end{tabular}


Table 5. Differences between industries regarding the import and export of virtual water between China and US in 2015 (unit: $10^{9} \mathrm{~m}^{3}$ ).

\begin{tabular}{|c|c|c|c|c|c|c|c|c|}
\hline \multirow{2}{*}{ Industry } & \multicolumn{2}{|c|}{ Green water } & \multicolumn{2}{|c|}{ Blue water } & \multicolumn{2}{|c|}{ Grey water } & \multicolumn{2}{|c|}{ Total } \\
\hline & Import & Export & Import & Export & Import & Export & Import & Export \\
\hline 1 & 6.9693 & 1.0039 & 1.0654 & 0.1860 & 1.2844 & 0.3413 & 9.3191 & 1.5311 \\
\hline 2 & 0.0035 & 0.0121 & 0.0005 & 0.0017 & 0.0011 & 0.0032 & 0.0051 & 0.0169 \\
\hline 3 & 0.0066 & 0.0016 & 0.0010 & 0.0003 & 0.0008 & 0.0008 & 0.0084 & 0.0027 \\
\hline 4 & 4.0192 & 2.0497 & 0.5594 & 0.3496 & 0.6769 & 0.5915 & 5.2555 & 2.9908 \\
\hline 5 & 0.1105 & 24.5328 & 0.0186 & 4.7272 & 0.0193 & 7.5928 & 0.1483 & 36.8528 \\
\hline 6 & 0.0585 & 3.5679 & 0.0082 & 0.4412 & 0.0091 & 2.0733 & 0.0758 & 6.0824 \\
\hline 7 & 0.2828 & 2.2438 & 0.0379 & 0.3969 & 0.0332 & 1.0536 & 0.3539 & 3.6943 \\
\hline 8 & 0.0907 & 0.5013 & 0.0133 & 0.1000 & 0.0160 & 1.4930 & 0.1201 & 2.0944 \\
\hline 9 & 3.8800 & 18.2090 & 0.5864 & 3.2484 & 0.5744 & 15.8825 & 5.0408 & 37.3398 \\
\hline 10 & 2.3582 & 0.7077 & 0.3365 & 0.1319 & 0.2514 & 0.5793 & 2.9461 & 1.4189 \\
\hline 11 & 0.0976 & 22.4155 & 0.0139 & 3.2358 & 0.0145 & 7.5749 & 0.1260 & 33.2263 \\
\hline 12 & 0.0000 & 0.0008 & 0.0000 & 0.0014 & 0.0000 & 0.1311 & 0.0000 & 0.1333 \\
\hline 13 & 0.0004 & 0.0000 & 0.0001 & 0.0000 & 0.0000 & 0.0000 & 0.0005 & 0.0000 \\
\hline 14 & 0.1550 & 0.0000 & 0.0224 & 0.0000 & 0.0146 & 0.0000 & 0.1920 & 0.0000 \\
\hline 15 & 0.0000 & 0.0000 & 0.0000 & 0.0000 & 0.0000 & 0.0000 & 0.0000 & 0.0000 \\
\hline 16 & 0.0000 & 0.0000 & 0.0000 & 0.0000 & 0.0000 & 0.0000 & 0.0000 & 0.0000 \\
\hline 17 & 0.0000 & 0.0000 & 0.0000 & 0.0000 & 0.0000 & 0.0000 & 0.0000 & 0.0000 \\
\hline 18 & 0.0011 & 0.0000 & 0.0001 & 0.0000 & 0.0002 & 0.0000 & 0.0014 & 0.0000 \\
\hline 19 & 0.1031 & 0.5139 & 0.0152 & 0.1041 & 0.0113 & 0.4368 & 0.1296 & 1.0548 \\
\hline 20 & 0.0506 & 0.0153 & 0.0073 & 0.0025 & 0.0049 & 0.0064 & 0.0628 & 0.0242 \\
\hline 21 & 0.1060 & 0.0924 & 0.0153 & 0.0147 & 0.0091 & 0.0389 & 0.1304 & 0.1460 \\
\hline 22 & 0.0181 & 0.0000 & 0.0026 & 0.0000 & 0.0012 & 0.0000 & 0.0219 & 0.0000 \\
\hline 23 & 0.2665 & 0.1211 & 0.0385 & 0.0200 & 0.0261 & 0.0491 & 0.3310 & 0.1902 \\
\hline 24 & 0.0031 & 0.0019 & 0.0004 & 0.0003 & 0.0004 & 0.0007 & 0.0039 & 0.0029 \\
\hline 25 & 0.0164 & 0.0000 & 0.0024 & 0.0000 & 0.0016 & 0.0000 & 0.0204 & 0.0000 \\
\hline 26 & 0.0001 & 0.0000 & 0.0000 & 0.0000 & 0.0000 & 0.0000 & 0.0001 & 0.0000 \\
\hline Total & 18.5974 & 75.9905 & 2.7454 & 12.9620 & 2.9505 & 37.8494 & 24.2932 & 126.8019 \\
\hline
\end{tabular}

Note: The names of those industries in Table 5 are the same those in Table 3, and a value of 0.0000 means the actual value is very minimal.

$\left(1.2844 \times 10^{9} \mathrm{~m}^{3}\right)$ and exported most grey water to Japan $\left(0.6630 \times 10^{9} \mathrm{~m}^{3}\right)$.

4) With respect to the totals of green, blue and grey water, in 2015 China's agricultural industry imported most virtual water from US $\left(9.3191 \times 10^{9} \mathrm{~m}^{3}\right)$ and exported most virtual water from Japan $\left(2.9745 \times 10^{9} \mathrm{~m}^{3}\right)$. Moreover, the total value for each country is consistent with the corresponding amount of virtual water trade by China's agriculturalindustry listed in Table 4.

Further on, the data of virtual water import and export between China and US are taken as examples to demonstrate the difference between industries regarding China's virtual water trade in 2015. The detailed results are shown in Table 5.

From Table 5 it can be concluded that:

1) China's agricultural industry (1) in 2015 imported most green and blue water from the US $\left(6.9693 \times 10^{9} \mathrm{~m}^{3}\right.$ and1.0654 $\times 10^{9} \mathrm{~m}^{3}$, respectively), and China's textiles and wearing apparel industry (5) exported most green and blue water to the US $\left(24.5328 \times 10^{9} \mathrm{~m}^{3}\right.$ and $4.7272 \times 10^{9} \mathrm{~m}^{3}$, respectively).

2) China's agricultural industry (1) in 2015 imported most virtual water from the US in terms of grey water 
alone $\left(1.2844 \times 10^{9} \mathrm{~m}^{3}\right)$ and the total of green, blue and grey water $\left(9.3191 \times 10^{9} \mathrm{~m}^{3}\right)$. Meanwhile, in 2015 China's electrical and machinery industry (9) exported most virtual water to the US in terms of grey water alone $\left(15.8825 \times 10^{9} \mathrm{~m}^{3}\right)$ and the total of green, blue and grey water $\left(37.3398 \times 10^{9} \mathrm{~m}^{3}\right)$.

3) The data for agriculture (1) are the same as those corresponding to US in Table 4; the total value for each industry is also consistent with the corresponding US value in Table 2.

\section{The Import and Export Trade Matrix of Virtual Water between China and Its Major Trading Partners around the World}

In order to further investigate the import and export of virtual water between China and its major trading partners (countries or regions) around the world, we further analyzed the trade matrix of virtual water in terms of green, blue and grey water, as shown in Table 6, Table 7 and Table 8.

The cells on the diagonals of Tables 6-8 are the consumptions of virtual water by the corresponding country (region) itself (can also be considered as domestic trade).

Other than those cells on the diagonals, the data on each row represent the export of virtual water from the country (region) of origin to other countries (regions); for example, the data on the third row of Table 6a), which are $5.1686,7.2453,7.0903,14.4898,48.1066,13.9887$, $4.7905,10.9697$ and $75.9905^{2}$, represent the amounts of virtual water export in the form of green water from China to Australia, Canada, France, Germany, Japan, South Korea, Russia, U.K., U.S. and ROW, respectively, in the year of 2015. Those data are in consistence with the corresponding ones listed in Table 2.

Similarly, the data on each column show the amounts of virtual water import to the country (region) of destination from other countries (regions). For instance, 13.4527 means the amount of virtual water import in the form of green water from Australia to China in 2015 was $13.4527 \times 10^{9} \mathrm{~m}^{3}$.

Regarding the consumption of virtual water:

1) Green water. Except for the value corresponding to ROW, the highest value on the diagonal in Table 6 is 4418.6754 (i.e. $4418.6754 \times 10^{9} \mathrm{~m}^{3}$ ), which indicates that the goods and services produced and consumed within China contained a lot of virtual water in the form of green water.

2) Blue water. Except for the ROW data, the highest value on the diagonal in Table 7 is 770.9455 (i.e. $770.9455 \times 10^{9} \mathrm{~m}^{3}$ ), which indicates that the goods and services consumed within China contained a lot of virtual water in the form of blue water.

3) Grey water. Except for the ROW data, the highest value on the diagonal in Table 8 is 1845.2709 (i.e.

\footnotetext{
The unit is $10^{9} \mathrm{~m}^{3}$.
}

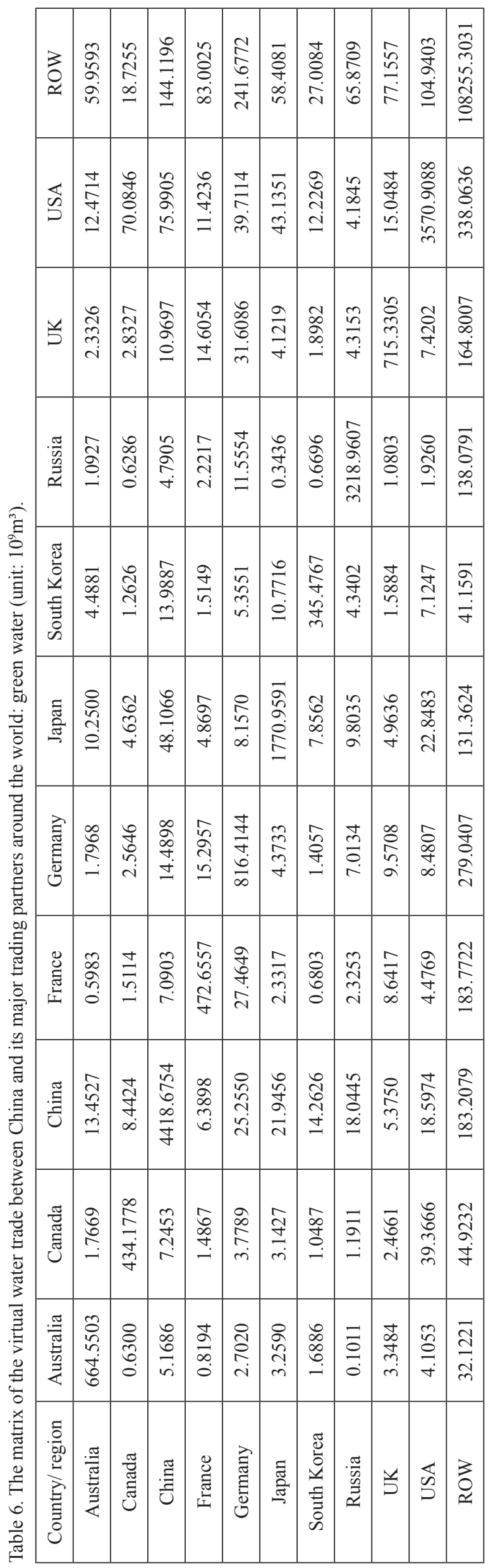




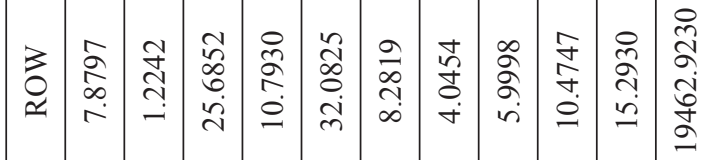

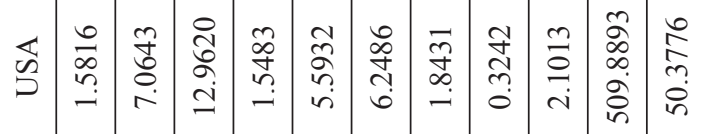

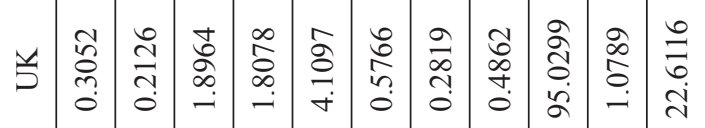

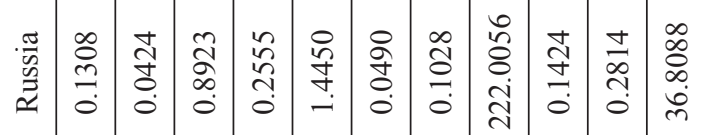

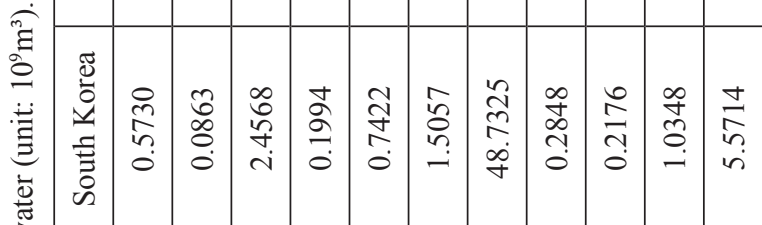

竞

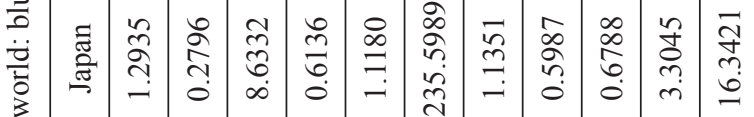

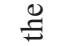

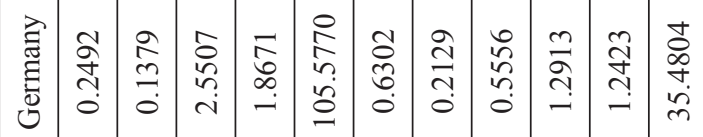

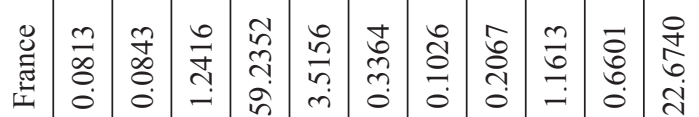

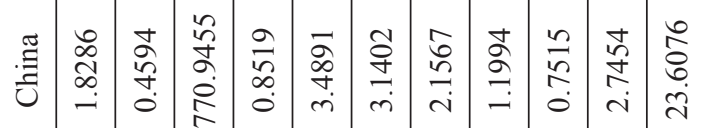

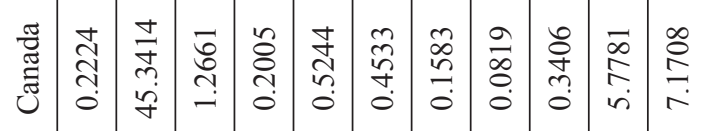

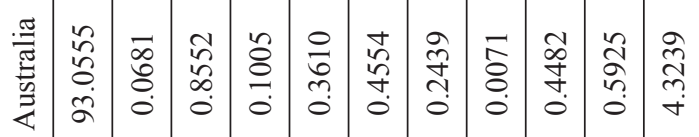

黄

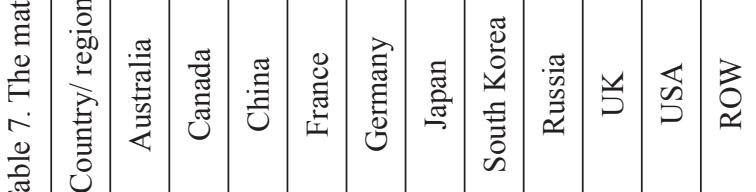

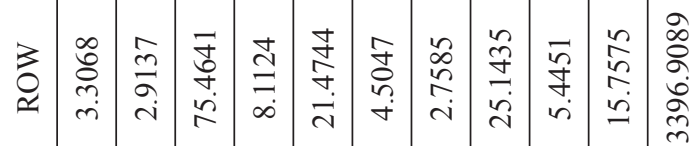

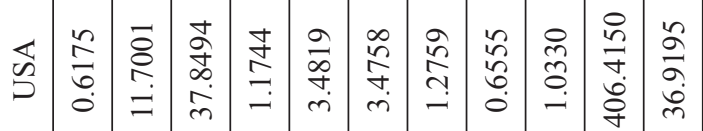

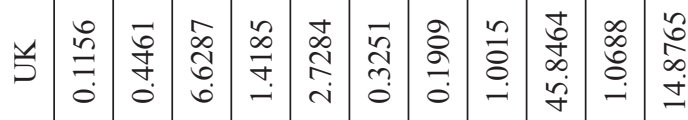

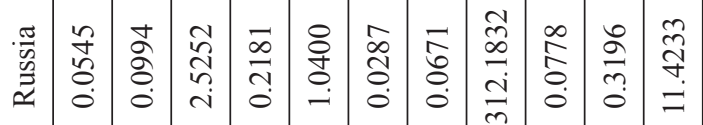

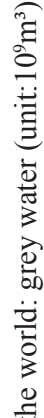

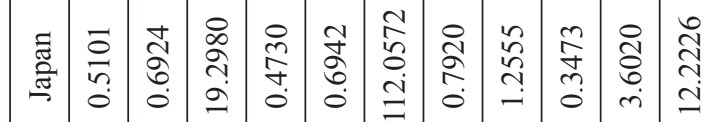

혼

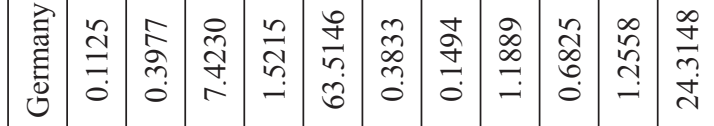

ฮ

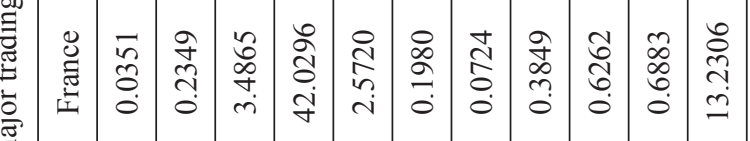

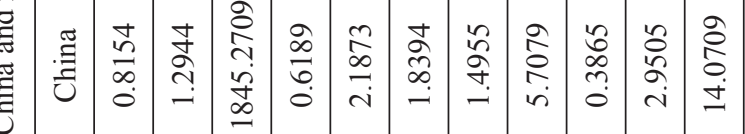
ธี

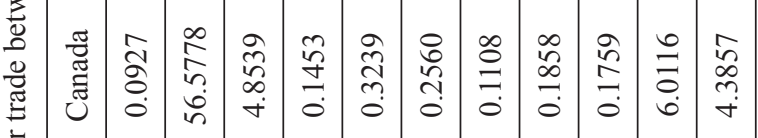

离

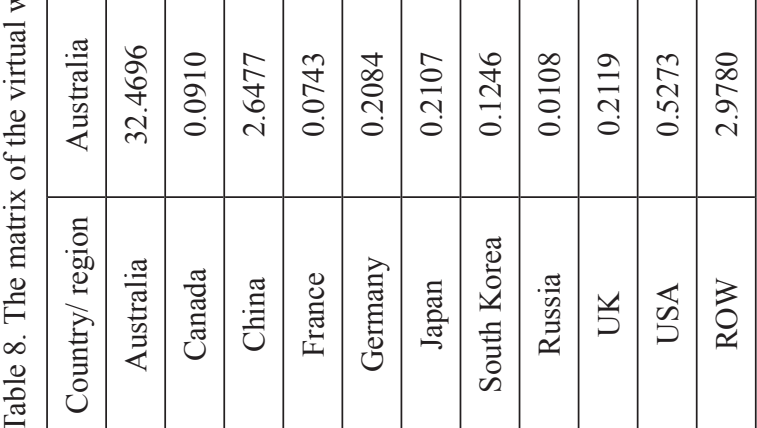


$\left.1845.2709 \times 10^{9} \mathrm{~m}^{3}\right)$, which indicates that the goods and services consumed within China contained a lot of virtual water in the form of grey water.

A large population will demand a lot of industrial and agricultural products as well as services; as China has the largest population in the world; it is not a surprise that China has consumed a lot of virtual water by itself.

Regarding the import of virtual water:

1) Green water. It can be told from Table 6 that, except for the ROW, Australia imported more green water from China than it did from any other country (referring to Canada, France, Germany, Japan, Korea, Russia, UK and US; the same hereinafter). This situation applies to Japan, Korea and US as well. Australia, Japan, Korea and US imported $5.1686 \times 10^{9} \mathrm{~m}^{3}$, $48.1066 \times 10^{9} \mathrm{~m}^{3}, 13.9887 \times 10^{9} \mathrm{~m}$ and $75.9905 \times 10^{9} \mathrm{~m}^{3}$ of green water from China, respectively.

2) Blue water. It can be seen from Table 7 that, except for the ROW, Australia imported more blue water from China than it did from any other country. This situation applies to Germany, Japan, Korea and US as well. Australia, Japan, Germany, Korea and US imported $0.8552 \times 10^{9} \mathrm{~m}^{3}, 2.5507 \times 10^{9} \mathrm{~m}^{3}$, $8.6332 \times 10^{9} \mathrm{~m}^{3}, 2.4568 \times 10^{9} \mathrm{~m}^{3}$ and $12.9620 \times 10^{9} \mathrm{~m}^{3}$ of blue water from China, respectively.

3) Grey water. It can be derived from Table 8 that, except for the ROW, Australia imported more grey water from China than it did from any other country. This situation applies to France, Germany, Japan, Korea, Russia, UK and US as well. Australia, France, Germany, Japan, Korea, Russia, UK and US imported $2.6477 \times 10^{9} \mathrm{~m}^{3}, 3.4865 \times 10^{9} \mathrm{~m}^{3}, 7.4230 \times 10^{9} \mathrm{~m}^{3}$, $19.2980 \times 10^{9} \mathrm{~m}^{3}, 6.4501 \times 10^{9} \mathrm{~m}^{3}, 2.5252 \times 10^{9} \mathrm{~m}^{3}$, $6.6287 \times 10^{9} \mathrm{~m}^{3}$ and $37.8494 \times 10^{9} \mathrm{~m}^{3}$ of grey water from
China, respectively. The large quantities of waste water generated by China's various industries led to large direct water-use coefficients and large overall water-use coefficients, resulting in large amounts of grey water exports from China to those countries.

Regarding the export of the virtual water:

1) Green water. It can be told from Table 6 that, except for the ROW, Australia exported more green water to China than it did to any other country (referring to Canada, France, Germany, Japan, Korea, Russia, UK and US; the same hereinafter). This situation applies to Korea and Russia as well. Australia, Korea and Russia exported $13.4527 \times 10^{9} \mathrm{~m}^{3}, 14.2626 \times 10^{9} \mathrm{~m}^{3}$ and $18.0445 \times 10^{9} \mathrm{~m}^{3}$ of green water to China, respectively.

2) Blue water. It can be seen from Table 7 that, except for the ROW, Australia exported more blue water to China than it did to any other country. This situation applies to Korea and Russia as well. Australia, Korea and Russia exported $1.8286 \times 10^{9} \mathrm{~m}^{3}, 2.1567 \times 10^{9} \mathrm{~m}^{3}$ and $1.1994 \times 10^{9} \mathrm{~m}^{3}$ of blue water to China, respectively.

3) Grey water. It can be derived from Table 8 that, except for the ROW, Australia exported more grey water to China than it did to any other country. This situation applies to Korea and Russia as well. Australia, Korea and Russia exported $0.8154 \times 10^{9} \mathrm{~m}^{3}, 1.4955 \times 10^{9} \mathrm{~m}^{3}$ and $5.7079 \times 10^{9} \mathrm{~m}^{3}$ of grey water to China, respectively.

Additionally, the comparison between the data on and not on the diagonals reveal thata value on the diagonal is always greater than other values for the corresponding country (region) not on the diagonal. This observation suggests that, for a particular country (region), the amount of virtual water (no matter in the form of green, blue or grey water) contained in the goods and services it consumed was always greater than that in the goods and services it imported or exported.

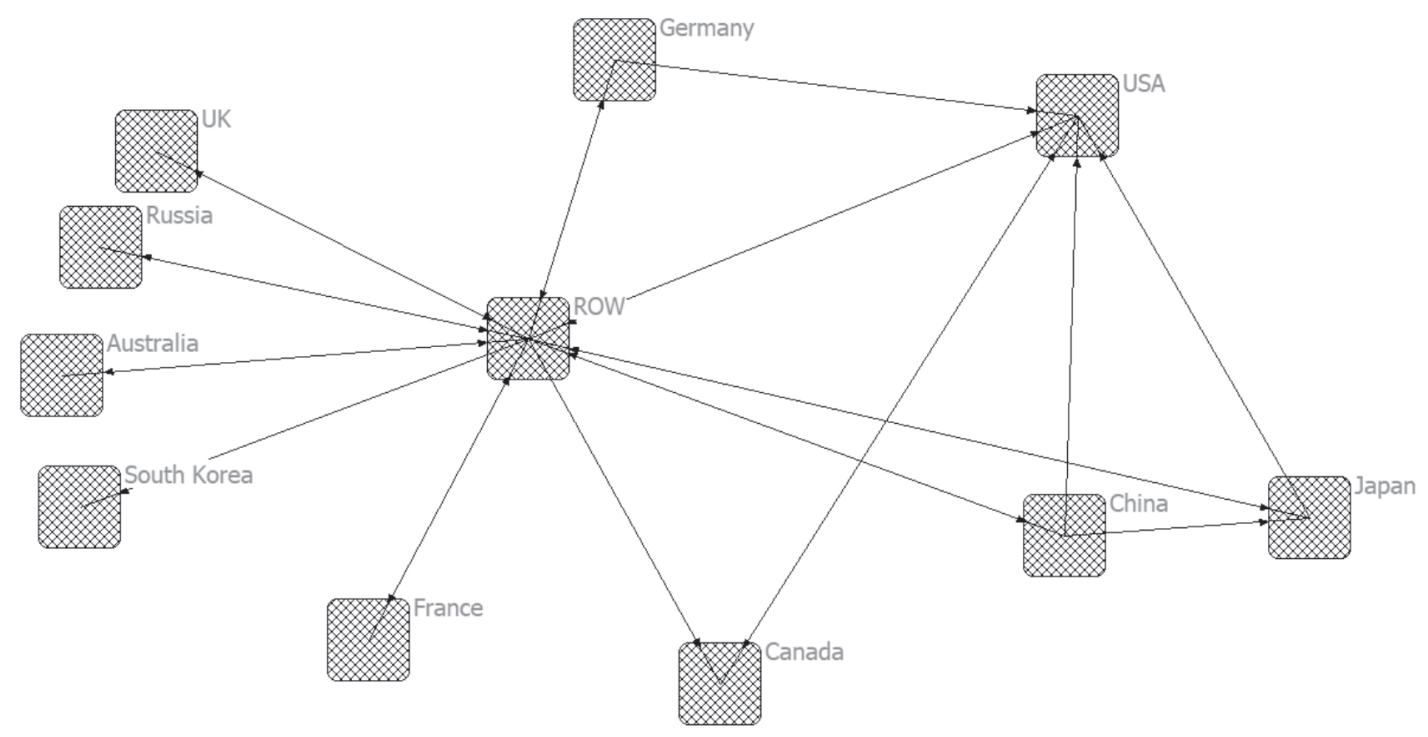

Fig. 1. The imports and exports of virtual water (the sum of green, blue and grey water) between China and other major countries (regions) in 2015. 
The reason lies in the fact that a country produces goods and services to meet its own needs first and only uses the remaining for trading.

To further understand the trade of virtual water in the forms of green, blue and grey water between China and its major trading partners, we used Ucinet 6 software to perform a visual data analysis. Fig. 1 shows a diagram illustrating the imports and exports of virtual water (the sum of green, blue and grey water) between China and other major countries (regions) in 2015.

In 2015, China traded virtual water with all of its major trading partners around the world. In order to better demonstrate the imports and exports of virtual water between different countries (regions), we have manipulated the data in the trade matrix of virtual water (the sum of green, blue and grey water) - which was obtained by adding up the corrupting values in Table 6, Table 7 and Table 8 - by performing the following treatment. At first, all the values on the diagonal were converted to 0 (i.e. self-consumption is considered as zero). Then, if a value was greater than the average amount of virtual water import/export $\left(38.7145 \times 10^{9} \mathrm{~m}^{3}\right)$, it was converted to 1 ; otherwise, that value was converted to 0 .

The arrows in Fig. 1 indicate the directions of virtual water exports. It can be seen that the arrows originating from China point to Japan, US and ROW, which means that the amounts of virtual water China exported to Japan, UW and ROW were all greater than the average. The only arrow pointing to China originates from ROW, which means that the amount of virtual water import from ROW to China was greater than the average. Moreover, due to the fact that ROW - which consists of many countries (regions) - has large volumes of imports and exports (therefore large amounts of virtual water trades), ROW in Fig. 1 has the highest number of connecting lines with other partners.

\section{Discussion}

Although the water resources in China are relatively short in supply, the calculation results shown by Table 2 still indicate a net export of virtual water. The main reason is that, besides water, the production of goods needs inputs of other factors like labor, capital, land and energy; benefiting from some advantages like an abundant labor force, China has still become a net exporter of goods and services despite its deficiency of water resources. Thus, calculations by Equation (5) and Equation (6) reveal China's position as a net exporter of virtual water. Similar results were reported and explained by Ansink [23], Reimer [24], Deng et al. [2], Deng et al. [21], etc. Moreover, since the wateruse coefficient for grey water was very different from those for green water and blue water, China's net export amount of grey water was greater than those of green water and blue water.
According to the results obtained from Table 2, in comparison with blue and grey water footprints, green water occupied the major portion of total virtual water trade between China and its major trading partners, no matter in the aspect of import or of export. Additionally, the data of virtual water imports by China's various industries listed in Table 3 suggest the reason why China imported a large amount of green water: in one aspect, China imports a huge number of agricultural products each year; in the other aspect, the process of agricultural production itself will consume a large amount of green water. In addition, according to the result of EORA26 database, the total amount of green water usage in 190 countries (regions) in 2015 is $1.26 \times 1014 \mathrm{~m}^{3}$, blue water usage is $2.19 \times 1013 \mathrm{~m}^{3}$, grey water usage is $6.68 \times 1012 \mathrm{~m}^{3}$. In the production or service procedure, the usage amount of green water is larger than blue and grey water, which means that to most countries (regions) and industries, the direct consumption coefficient of green water is larger than that of blue water and gray water. So according to formula (5) to (8), for most countries (regions) and industries, the virtual water trade volume of green water should be the largest. In that sense, there are limitations that the existing works (such as Deng et al. [1]) only focused on the trade of virtual water in the form of blue water.

As a method to study societal actors and their relationships, social network analysis was applied primarily to sociological research when it was first introduced and now has been adopted in the studies of international trade. For example, Kim and Shin [25] used social network analysis to study the globalization and regionalization of international trade, pointing out that globalization and regionalization of international trade are not contradictory. Hall et al. [26] utilized social network analysis to study the global pistachio trade from 1996 to 2000, concluding that American pistachios are increasingly exported to countries that implement stricter aflatoxin standards. Different from the existing literatures on international trade of products or services, this work draws on the methodology of social network analysis and visualizes the virtual water trade between China and its major trading partners around the world with the help of Ucinet6 software. In addition, the existing literatures to investigate virtual water trade $[9,21]$ did not employ any method of social network analysis, either.

\section{Conclusions}

This work is based on the perspective of global value chains and utilizes the multi-regional inputoutput table and water footprint data of 2015 from the EORA26 database to study China's virtual water trade in the year of 2015 with respect to the differences between countries and industries. The research results indicate that: 
(1) China was a net exporter of virtual water for all the three types of water footprints: green, blue and grey. More specifically, China was a net exporter of green water to Australia, German, Korea and Russia, a net importer of blue water from Australia, German and Russia, and a net importer of grey water from Russia. In addition, based on the trade data of green, blue and grey water footprints, it can be seen that, among all the major trade partners, China imported the most amount of the virtual water from Germany $\left(30.9314 \times 10^{9} \mathrm{~m}^{3}\right)$ and the biggest importer of China's virtual water was the US $\left(126.8019 \times 10^{9} \mathrm{~m}^{3}\right)$.

(2) When the amounts of green, blue and grey water are added up together, the largest industry of imported virtual water usage was agriculture $\left(127.5812 \times 10^{9} \mathrm{~m}^{3}\right)$, while the textiles and wearing apparel industry exported the largest volume of virtual water $\left(158.9046 \times 10^{9} \mathrm{~m}^{3}\right)$. However, when only grey water is considered, China's electrical and machinery industry both imported and exported the highest amounts of virtual water.

Based on the above results, it is suggested to policy makers that:

(1) In order to relieve the pressure of water supply in China, the amount of virtual water exported to the US should be appropriately reduced and the amount of virtual water imported from Germany should be increased. However, besides the usage of water resources, the production of various goods and the offering of various services also require other resources like capital, labor, land and energy; therefore, while alleviating the pressure on water supply, we should also pay attention to whether other resources factors are sufficient.

(2) Meanwhile, China should properly control the export of textile products and import more agricultural products such as grains. Moreover, China needs to learn from other countries in the fields of advanced water-saving and emission-reduction technologies, improving the efficiency of water use and lowering the consumption of green, blue and grey water resources per unit product.

(3) When formulating water-saving policies, the Chinese government should pay attention to the differences between green water, blue water and gray water. From the water-saving perspective, the comprehensive utilization of rainwater (green water) needs to be strengthened. From the economic cost perspective, the price per cubic meter of blue water is the highest, so the import volume for industries that consume more blue water (such as Agriculture, Electrical and Machinery) can be moderately increased. From the environmental pollution perspective, moderately control the production of products with large sewage discharge (large amount of gray water used), and control the export for industries (Electrical and Machinery) with large sewage discharge (large amount of gray water used).

(4) With the global economic integration background, countries (regions) in the world should gradually remove trade barriers, strengthen the construction of transportation facilities, promote trade in products and services, and expand virtual water trade, thereby alleviating the contradiction between global water supply and demand.

The shortcoming of this paper is that only the 2015 data are studied. In addition, the calculating of virtual water trade is only at the macro industry level rather than going more specifically to the crop level. The reasons why only the 2015 data are chosen are listed as follows: (1) Due to the complex procedure of making world input-output tables, the 2015 data is already the latest. (2) When calculating water footprint in EORA26 database, it is assumed that the direct water use coefficient (according to formula 3 ) in the same country (region) and the same industry remains the same every year. For example, the direct water use coefficient data of China Ministry of Agriculture in 2014 and 2015 are the same. However, even in the same department in one country, the direct water use coefficient data should be different every year. The deficiency for using the 2015 data alone is that the trend of virtual water trade in China cannot be analyzed. The methodology of this paper is still applicable to the study of other years. In addition, EORA26 database haven't provided the world input-output tables and data of water footprint usage specifically to a certain kind of crop, so the study of this paper remains at the macro industry level.

\section{Acknowledgements}

This work was supported by the Natural Science Foundation of China under Grant [number 71704070]; Ministry of Education for the Humanities and Social Sciences Research Young Fund on the West and Borderland Project [number 17XJC790002], Gansu Provincial Higher Education Research Project [number 2020A-058]; and Program of Lanzhou University of Finance and Economics under Grant [number Lzufe2018B-06]; and Outstanding Youth Fund of Gansu Province[number 20JR5RA206].

\section{Conflict of Interest}

The authors declare no conflict of interest.

\section{References}

1. DENG G., LI L., SONG Y. Provincial water use efficiency measurement and factor analysis in China: Based on SBMDEA model. Ecological Indicators, 69, 12, 2016.

2. DENG G., WANG L., XU X. Linkage effect of virtual water trade in China's industrial products - based on generalized hypothetical extraction method. Ecological Indicators, 93, 1302, 2018.

3. ALLAN J.A. Fortunately there are substitutes for water otherwise our hydropolitical futures would be 
impossible. Priorities for Water Resources Allocation and Management. ODA, London. 1993.

4. HOEKSTRA A.Y., HUNG P.Q. Virtual water trade: a quantification of virtual water flows between nations in relation to international crop trade. Value of Water Research Report Series 11. IHE Delft, The Netherlands. 2002.

5. HOEKSTRA A.Y., CHAPAGAIN A.K., ALDAGA M., MEKONNEN M. M.The water footprint assessment manual: Setting the global standard. Earthscan, Abingdon, UK. 2011

6. DANG Q., LIN X., KONAR M. Agricultural virtual water flows within the United States. Water Resources Research, 51 (2), 973, 2015.

7. SUN S., WANG Y., ENGEL B.A., WU P. Effects of virtual water flow on regional water resources stress: A case study of grain in China. 550, 871, 2016.

8. ZHUO L., MEKONNEN M.M., HOEKSTRA A.Y. The effect of inter-annual variability of consumption, production, trade and climate on crop-related green and blue water footprints and inter-regional virtual water trade: A study for China (1978-2008). Water Research, 94, 73, 2016.

9. ZHANG Y., WANG C., CAO J., ZHANG J., WANG L., LIU Z. China and Trans-Pacific partnership agreement countries: Estimation of the virtual water trade of agricultural products. Journal of Cleaner Production, 140, 1493, 2017.

10. LAMASTRA L., MIGLIETTA P.P., TOMA P., DE LEO F., MASSARI S. Virtual water trade of agri-food products: Evidence from Italian-Chinese relations. Science of The Total Environment, 599, 474, 2017.

11. DONG H., GENG Y., FUJITA T., FUJII M., HAO D., YU X. Uncovering regional disparity of China's water footprint and inter-provincial virtual water flows. Science of The Total Environment, 500-501, 120, 2014.

12. JIANG Y., CAI W., DU P., PAN W., WANG C. Virtual water in interprovincial trade with implications for China's water policy. Journal of Cleaner Production, 87, 655, 2015.

13. ZHI Y., HAMILTON P.B., ZHI C. Analysis of virtual water consumption in China: using factor decomposition analysis based on a weighted average decomposition model. Water and Environment Journal, 29 (1), 61, 2015.
14. SERRANO A., GUAN D., DUARTE R., PAAVOLA J. Virtual water flows in the EU27: A consumption- based approach. Journal of Industrial Ecology, 20 (3), 547, 2016.

15. ZHI Y., HAMILTON P.B., WANG X., LIANG L. Water footprint assessment considering intermediate products: Model and a 2016 case study of China. Water and Environment Journal, 33 (2), 230, 2019.

16. ZHANG C., ANADON L.D. A multi-regional input-output analysis of domestic virtual water trade and provincial water footprint in China. Ecological Economics, 100, 159, 2014.

17. WU S., BEN P., CHEN D., CHEN J., TONG G., YUAN Y., XU B. Virtual land, water, and carbon flow in the inter-province trade of staple crops in China. Resources Conservation and Recycling, 136, 179, 2018.

18. CHEN W., WU S., LEI Y., LI S. Virtual water export and import in china's foreign trade: A quantification using input-output tables of China from 2000 to 2012. Resources Conservation and Recycling, 132, 278, 2018.

19. LENZEN M., KANEMOTO K.., MORAN D., GESCHKE A. Mapping the structure of the world economy. Environmental Science and Technology, 46 (15), 8374, 2012.

20. LENZEN M., MORAN D., KANEMOTO K., GESCHKE A. Building Eora: A global multi-regional input-output database at high country and sector resolution. Economic Systems Research, 25 (1), 20-49, 2013.

21. DENG G., MA Y., LI X. Regional water footprint evaluation and trend analysis of China - based on interregional input-output model. Journal of Cleaner Production, 112, 4674, 2016.

22. HOU S., LIU Y., ZHAO X., TILLOTSON M., GUO W., LI Y. Blue and green water footprint assessment for China - A multi-region input-output approach. Sustainability, 10, 2822, 2018

23. ANSINK E. Refuting two claims about virtual water trade. Ecological Economics, 69 (10), 2027, 2010.

24. REIMER J.J. On the economics of virtual water trade. Ecological Economics, 75 (2), 135, 2002.

25. KIM S., SHIN E.H. A longitudinal analysis of globalization and regionalization in international trade: A social network approach. Social Forces 81 (2), 445, 2002.

26. HALL G., HASDAY J.D., ROGERS T.B. Aflatoxin regulations and global pistachio trade: Insights from social network analysis. Plos One, 9 (3), 1, 2014 